\title{
MODEL KOOPERATIF WHO AM I MENGGUNAKAN ZOOM MENDORONG LITERASI ANAK DALAM PEMBELAJARAN DARING
}

\author{
${ }^{1}$ Agung Prihatmojo, ${ }^{2}$ Elizar, ${ }^{3}$ Febri Kiswanto ${ }^{3}$ \\ agung.prihatmojo@umko.ac.id
}

\section{Universitas Muhammadiyah Kotabumi}

\begin{abstract}
Technological advances can help learning during the Covid-19 pandemic. The development of internet-based technology provides zoom video conference applications. The use of zoom helps teachers and students in virtual face-to-face interactions separated by space and distance. The Who Am I cooperative model uses zoom meetings to stimulate student literacy in online learning so as to increase literacy during the Covid 19 pandemic. Literacy stimulation is an inner drive (without coercion) to carry out reading and writing activities. Who Am I model that uses game tournaments as a learning-while-playing strategy. Learning while playing is able to provide a good stimulus for literacy activities. The characteristics of the Who Am I learning model provide a stimulus to literacy. These characteristics are: 1) learning in groups, 2) learning while playing, 3) fun learning, 4) learning vocabulary mastery.
\end{abstract}

keywords : Online Learning, Who Am I Model, Literacy Stimulation

Abstrak: Kemajuan teknologi dapat membantu pembelajaran di masa pandemi Covid-19. Perkembangan teknologi berbasis internet menyediakan aplikasi video conference zoom. Penggunaan zoom membantu guru dan siswa dalam interaksi tatap muka virtual yang terpisah ruang dan jarak. Model kooperatif Who Am I menggunakan zoom meeting memberi stimulasi literasi siswa dalam pembelajaran daring sehingga meningkatkan literasi di masa pandemi Covid 19. Stimulasi literasi adalah dorongan dalam diri (tanpa paksaaan) untuk melakukan aktivitas membaca dan menulis. Model Who Am I yang menggunakan turnamen game sebagai strategi belajar sambil bermain. Belajar sambil bermain ternyata mampu memberi stimulus yang baik untuk kegiatan literasi. Karakteristik model pembelajaran Who Am I memberi stimulus terhadap literasi. Karakteristik tersebut, yaitu: 1) pembelajaran secara kelompok, 2) pembelajaran sambil bermain, 3) pembelajaran yang menyenangkan, 4) pembelajaran penguasaan kosakata.

Kata Kunci: Pembelajaran Daring, Model Who Am I, Stimulasi Literasi

\section{PENDAHULUAN}

Penyebaran Virus Covid-19 sudah merata keseluruh belahan dunia. Berbagai upaya pencegahan dilaku- kan setiap negara agar mengurangi jumlah pasien Covid-19. Pencegahan penyebaran Covid-19 di
Indonesia pada bidang pendidikan dengan menutup kegiatan belajar mengajar di sekolah mengganti dengan pembel- ajaran jarak jauh/daring. Haqien \& Rahman (2020) menyebutkan untuk mencegah penyebaran virus corona maka kegiatan belajar mengajar di sekolah harus dilakukan di 
rumah secara online. Hal itu sesuai keputusan menteri pendidikan dan kebudayaan Republik Indonesia terkait surat edaran nomor 4 tahun 2020 tentang pelaksanaan kebijakan pendidikan dalam masa darurat penyebaran Covid-19 yang memutuskan untuk menetapkan metode pembelajaran daring.

Kemajuan teknologi dapat membantu pembelajaran di masa pandemi Covid-19. Penggunaan teknologi internet sudah lazim untuk pembelajaran di masa pandemi Menurut Prihatmojo, dkk. (2019) proses pembelajaran harus mampu beradaptasi terhadap internet seiring perkembangan teknologi di abad 21 . Kemudian menurut Nugroho (2012) sebagai sarana belajar, internet dapat memberi dampak yang positif sehingga menciptakan pembelajaran yang efektif. Menurut Hanum (2013) dengan memanfaatkan teknologi informasi dan komunikasi dengan maksimal sebagai pendukung me- rupakan bagian dari pembelajaran yang efektif. Perkembangan tekno- logi berbasis internet menyediakan aplikasi video conference zoom. Penggunaan zoom membantu guru dan siswa dalam interaksi tatap muka virtual yang terpisah ruang dan jarak. Menurut Sandiwarno (2016) pem- belajaran yang ideal merupakan kombinasi interaksi antara pendidik dan peserta didik. Dengan bantuan video conference akan membantu proses belajar mengajar meskipun mereka tidak ada dalam satu tempat. Menurut Kirana, dkk (2020) Zoom Cloud Meeting merupakan aplikasi yang menyediakan fasilitas interaksi tatap muka antara pendidik dan peserta didik. Kegiatan tersebut dapat dilakukan dengan PC, smartphone, atau laptop.

Pada masa pandemi Covid-19 penerapan pembelajaran daring dapat menyebabkan rendahnya literasi siswa. Peningkatan kegiatan literasi merupakan tantangan guru pada pembelajaran daring. Menunut Pangondian, dkk. (2019) di masa pandemik, guru memiliki tantangan literasi dalam proses belajar mengajar. Menurut Gani, A. R. F., \& Arwita, W. (2020) siswa yang memiliki kemampuan literasi yang rendah akan kesilitan dalam belajar ketika dilakukan secara online atau daring. Rendahnya kemampuan literasi dalam jangka panjang akan menyebabkan penurunan pengetahu- an koqnitif dan ketertinggalan belajar. Di dalam Kemdikbud (2017) disampaikan bahwa kemampuan literasi di Indonesia dengan nilai $46,83 \%$ berada pada katagori kurang. Kemudian untuk nilai $6,06 \%$ berada pada kategori baik, dan $47,11 \%$ berada pada katagori cukup. Data tersebut menunjukkan kebiasaan atau kegemaran membaca di kalangan siswa rendah sehingga dipastikan kesulitan belajar di masa pandemi Covid19. 


\section{PEMBAHASAN}

\section{Model Who Am I}

Guru membutuhkan model pembelajaran yang dapat meningkat- kan budaya literasi. Menurut Wulanjani, A. N., \& Anggraeni, C. W. (2019) untuk memberikan dampak positif, khususnya tentang budaya literasi dapat dilakukan dengan penerapan kegiatan yang tepat. Model kooperatif Who Am I menggunakan zoom meeting mem- beri stimulus literasi siswa dalam pembelajaran daring sehingga meningkatkan literasi di masa pandemi Covid 19. Menurut Prihatmojo \& Rohmani (2020) untuk meningkatkan literasi di sekolah secara efektif dapat dilakukan dengan model pembelajaran kooperatif berbasis literasi berkarak- ter game Who Am I.

Model pembelajaran Who Am I merupakan bagian dari model pembelajaran kooperatif TGT yang dapat meningkatkan literasi. Model pembelajaran Who Am I mempunyai aturan main yang unik karena berfokus pada bahan ajar teks deskriptif dan menggunakan kata-kata sebagai kunci permainan. Menurut Prihatmojo (2020) kegiatan dengan cara menyingkat huruf depan dari sebuah kata merupakan per- mainan dari Who Am I (siapakah aku). Singkatan kemudian digunakan guru untuk menjadi sebuah per- tanyaan siapakah aku. Kata yang disingkat minimal satu kata dan maksimal empat kata. Sedangkan menurut Khoerul Muzakqy, dkk. (2018) Who Am I adalah tehnik yang dilakukan oleh peserta didik dengan membuat kelompok kecil untuk memenangkan sebuah tantangan. Tantangan tersebut dapat diaplikasi- kan dengan menarik dalam kelas dengan menebak objek. Objek tersebut dideskripsikan oleh grup lawan kemudian kalimat yang di keluarkan oleh tim lawan adalah klue untuk menebak objek apa yang dimaksudkan.

Miftahul Huda (2011) mengata- kan bahwa turnamen tersebut dapat dinikmati oleh siswa dan mereka berkompetisi dengan kelompok yang memiliki komposisi kemampuan yang setara. Model Who Am I menyajikan peluang yang sama dimiliki setiap pemain (siswa) untuk memenangkan turnamen. Namun, siswa yang banyak membaca, memahami, mengingat bahan ajar teks deskriptif secara berulang-ulang akan berpotensi lebih besar untuk dapat menjawab setiap pertanyaan.

Model Who Am I juga menarik antusias siswa untuk semangat belajar. Menurut Mohammad Alan Arrosy Bimantara (2012) untuk menarik minat siswa dalam mengikuti kegiatan belajar mengajar dapat dilakukan dengan permainan Who Am I. permainan tersebut terbukti dapat membantu mereka dalam 
merangkai ide-ide ketika mereka tampil berbicara.

\section{Who Am I Menggunakan Zoom Meeting}

Model Pembelajaran Who Am I menggunakan zoom meeting mendukung dalam proses pem- belajaran daring. Menurut Haqien \& Rahman (2020) dengan meng- gunakan zoom seseorang dapat menggunakannya secara gratis dengan batas waktu empat puluh menit. Kemudian jika akun tersebut berbayar maka dapat digunakan tanpa batasan waktu. Seseorang dapat beromunikasi secara langsung melalui aplikasi Zoom Meeting. Oleh karena itu, aplikasi tersebut cocok sebagai media pembelajaran. Menurut Liu \& Ilyas (2020) zoom cloud meetings (ZCM) merupakan aplikasi dengan konsep screen sharing. Dapat digunakan lebih dari 100 orang partisipan untuk bertatap muka. Aplikasi ini juga dapat diunduh di smartphone.

Zoom meeting dapat menjadi sarana penggunaan model Who Am I secara online. Menurut Haqien \& Rahman (2020) zoom meeting ini merupakan aplikasi yang lebih praktis untuk komunikasi di- bandingkan secara tertulis atau melalui chat. Guru dapat meng- gunakan model pembelajaran Who Am I dengan zoom meeting untuk kegiatan literasi. Hal tersebut karna zoom dapat memfasilitasi share screen bahan ajar, chat dan video conference. Fitur penting adalah share dokumen untuk kegiatan literasi membaca dan video conference untuk berlangsungnya game Who Am I. Share dokumen digunakan guru untuk membagikan materi bacaan teks deskriptif. Terdapat pula fitur chat yang dapat digunakan guru untuk kegiatan menulis siswa. Menurut Sandiwarno (2016) pendidik dapat menampilkan materinya dalam zoom dan dapat dilihat oleh semua partisipan.

Sintaks model Who Am I menonjolkan kegiatan literasi mem- baca dan menulis. Kegiatan membaca dan menulis siswa dapat diinte- grasikan dalam model pembelajaran Who Am I menggunakan zoom. Menurut La Hewi (2020) penge- tahuan dan keterampilan yang berkaitan dengan kemampuan mem- baca dan menulis merupakan literasi awal yang ada pada anak. Materi game yang berupa bahan ajar yang berbentuk teks deskriptif. Menurut prihatmojo (2020) permainan Who Am I dapat diawali dari pemilihan bahan ajar. Pemilihan tersebut berupa bahan bacaan berbasis karakter yang disesuaikan dengan materi pelajaran. Dengan begitu dalam penerapan model Who Am I banyak sekali kegiatan literasi yang terdesain dalam permainan 
Karakteristik Model Who Am I Menstimulasi Literasi

Model pembelajaran koopera- tif Who Am I merupakan model yang diterapkan dengan cara bermain game Who Am I secara berkelompok kecil. Pada masa pandemi guru tetap bisa membentuk kelompok melalui zoom. Setiap kelompok berlomba untuk menjadi pemenang dalam permainan Who Am I. Model Who Am I merupakan permainan kosakata dengan singkatan yang menekankan pada kemampuan literasi.

Stimulasi literasi adalah dorongan dalam diri (tanpa paksaaan) untuk melakukan aktivitas membaca dan menulis. Model Who Am I yang menggunakan langkah belajar sambil bermain ternyata mampu memberi stimulus yang baik untuk kegiatan literasi. Menurut Jazariyah \& Durtam (2019) untuk meningkatkan perkem- bangan anak dapat dilakukan dengan kegiatan bermain. Beberapa karakteristik yang dimiliki oleh model Who Am I yang memberi stimulus terhadap literasi sebagai berikut:

\section{Pembelajaran Secara Kelompok} Model pembelajaran Who Am I diterapkan dengan pembelajaran secara berkelompok-kelompok kecil (kooperatif). Menurut Prihatmojo (2020) untuk memberi dorongan kepada siswa dapat dilakukan dengan pembelajaran kooperatif. kegiatan Pembelajaran kooperatif model Who Am I mempunyai langkah awal yaitu kegiatan literasi membaca materi teks sebagai bekal menjawab pertanyaan pada game Who Am I. Sudah tentu hal ini mendorong setiap kelompok untuk berlomba memenangkan per- mainan dengan cara mendorong anggota dalam setiap kelompok tersebut untuk membaca materi pembelajaran.

2. Pembelajaran Sambil Bermain Model pembelajaran Who Am I dilaksanakan dengan konsep belajar sambil bermain, sehingga siswa termotivasi memenangkan game Who Am I. Menurut Lisnawati Ruhaena (2015) Stimulasi melalui bermain yang dapat menarik minat anak sehingga anak tidak merasa kesulitan untuk focus, tidak mudah bosan dan capek. Anak membutuhkan stimulasi yang tidak dirasakan sebagai belajar tetapi sebagai bermain yang sesuai dengan kebutuhan perkembangannya.

3. Pembelajaran yang Menyenangkan Pembelajaran who am I mempunyai karakteristik yang menyenangkan karena menggunakan permainan seba- gai pembelajaran. Menurut Surisno (2017) kegiatan literasi tentunya dapat dikembangkan dengan cara yang menyenangkan. Dengan begitu siswa tidak akan merasakan adanya paksaan dalam 
pembelajarannya. Pembelajaran yang menyenangkan dapat memberi stimulus yang baik untuk kegiatan literasi. Menurut Setiyati (2017) kegiatan belajar mengajar dengan adanya permainan akan membuat siswa menjadi senang dan tertarik mengikuti pembelajaran.

\section{Pembelajaran Penguasaan Kosakata} Game pada pembelajaran Who Am I menggunakan singkatan kata-kata dalam pertanyaan, sehingga penguasaan kosakata sangat diperlu- kan dalam permainan game Who Am I. Menurut Aulina (2012) melalui permainan dan penguasaan kosakata berpengaruh positif terhadap kemam- puan membaca.

Dari empat karakteristik diatas dapat menunjukkan bahwa model pembelajaran Who Am I dapat menstimulasi literasi. Hal ini sesuai dengan pendapat Lisnawati Ruhaena (2015) stimulasi literasi anak yaitu rangsangan yang terintegrasi dalam situasi bermain yang menyenangkan sehingga merangsang semua sensoris anak. Model pembelajaran game Who Am I menggunakan zoom mampu menjadi media belajar sambil bermain yang menyenangkan di masa pembelajaran daring.

\section{SIMPULAN}

Kemajuan teknologi internet khususnya platform video confe- rence menjadi penunjang utama pembelajaran jarak jauh. Platform video conference Zoom Meeting mampu mendukung pembelajaran jarak jauh dengan fitur video conference, share screen dan chat. Fitur tersebut dapat menjadi sarana media dalam penerapan model Who Am I. Model Who Am I yang dapat menstimulus kegiatan literasi. Literasi yang dapat dilakukan dalam game Who Am I berbasis zoom adalah membaca, dan menulis bahan teks deskriptif. Semua bahan bacaan yang dibagikan lewar fitur share screen dan berisi materi-materi untuk menjawab game Who Am I.

\section{DAFTAR PUSTAKA}

Alan Arrosy B, M (2013). The Implementation Of "Who Am I" Game To Teach Speaking Descriptive Text To The Seventh Graders Of SMPN 3 Krian. RETAIN, 1(3).

Aulina, C. N. (2012). Pengaruh Permainan dan Penguasaan Kosakata terhadap Kemampuan Membaca Permulaan Anak Usia 5-6 tahun. Pedagogia: Jurnal Pendidikan, 1(2), 131-144. 
Gani, A. R. F., \& Arwita, W. (2020). Kecenderungan Literasi Informasi Mahasiswa Baru Pada Mata Kuliah Morfologi Tumbuhan. Jurnal Pelita Pendidikan, 8(2).

Hanum, N. S. (2013). Keefektifan E-Learning sebagai Media Pembelajaran (Studi Evaluasi Model Pembelajaran E-learning SMK Telkom Sandhy Putra Purwokerto). Jurnal Pendidikan Vokasi, 3(1).

Haqien, D., \& Rahman, A. A. (2020). Pemanfaatan Zoom Meeting Untuk Proses Pembelajaran Pada Masa Pandemi Covid-19. SAP (Susunan Artikel Pendidikan), 5(1).

Hewi, L., \& Asnawati, L. (2020). Strategi Pendidik Anak Usia Dini Era Covid-19 dalam Menumbuhkan Kemampuan Berfikir Logis. Jurnal Obsesi: Jurnal Pendidikan Anak Usia Dini, 5(1), 158-167.

Huda, Miftahul. (2011). Cooperative Learning. Yogyakarta: Pustaka Belajar

Jazariyah, J., \& Durtam, D. (2019). Pendampingan Pembuatan Alat Permainan Edukatif (APE) Pengenalan Literasi Untuk Anak Usia Dini. Dimasejati: Jurnal Pengabdian Kepada Masyarakat, 1(2).

Kemdikbud, R. I. (2017). Panduan Pengembangan Pembelajaran Aktif. Jakarta: Direktorat Pembinaan SMA.

Kirana, K. C., Wibawanto, S., \& Cahyono, G. P. (2020, September). Design of Teleconferencebased Learning Management System for a Learning Tool in the Co-19 Pandemic. In 2020 4th International Conference on Vocational Education and Training (ICOVET) (pp. 8186). IEEE.

Liu, A. N. A. M. M., \& Ilyas, I. (2020). Pengaruh Pembelajaran Online Berbasis Zoom Cloud Meeting Terhadap Hasil Belajar Mahasiswa Fisika Universitas Flores. Jurnal Pendidikan Fisika Dan Keilmuan (JPFK), 6(1), 34-38.

Muzakqy, K., Suharno, S., \& Suwandi, S. (2018). Penggunaan Who Am I Game Untuk Meningkatkan Kemampuan Membaca Peserta Didik Dalam Pembelajaran Teks Deskripsi Pada Kelas 10 SMA Negeri 6 Semarang Tahun Ajaran 2018/2019. Media Penelitian Pendidikan: Jurnal Penelitian dalam Bidang Pendidikan dan Pengajaran, 12(2), 157-168.

Nugroho, Y. (2012). Localising the Global, Globalising the Local: The Role of the Internet in Shaping Globalisation Discourse in Indonesian NGOs. Journal of international Development, 24(3), 341-368.

Pangondian, R. A., Santosa, P. I., \& Nugroho, E. (2019, February). Faktor-faktor yang mempengaruhi kesuksesan pembelajaran daring dalam revolusi industri 4.0. In Seminar Nasional Teknologi Komputer \& Sains (SAINTEKS) (Vol. 1, No. 1).

Prihatmojo, A., \& Rohmani, R. (2020). Pengembangan Model Pembelajaran Kooperatif Berbasis Literasi Berkarakter dengan Game Who Am I. JOEAI: Journal of Education and Instruction, 3(2), 312-321. 
Prihatmojo, A., \& Rohmani, R. (2020). Buku Ajar Pengembangan Model Pembelajaran" Who Am I".

Prihatmojo, A., Agustin, I. M., Ernawati, D., \& Indriyani, D. (2019). Implementasi Pendidikan Karakter Di Abad 21. SEMNASFIP.

Sandiwarno, S. (2016). Perancangan Model E-Learning Berbasis Collaborative Video Conference Learning Guna Mendapatkan Hasil Pembelajaran yang Efektif dan Efisien. Jurnal Ilmiah FIFO, 8(2), 191-200.

Setiyati. (2017). Pemanfaatan Media Kartu Kuis Who Am I Untuk Materi Ajar Sumber Daya Alam Keragaman Suku Bangsa Dan Budaya. Institute of Research Publishing Project Journal .Vol 18, No 2

SUTRISNO, M. D. (2017). Penggunaan Media Permainan Sebagai Upaya Membangun Literasi Dini (Doctoral dissertation, Universitas Airlangga.

Wulanjani, A. N., \& Anggraeni, C. W. (2019). Meningkatkan minat membaca melalui gerakan literasi membaca bagi siswa sekolah dasar. Proceeding of Biology Education, 3(1), 26-31. 